\title{
Population demography and spatial distribution of the mantis shrimp Squilla biformis (Stomatopoda, Squillidae) from Pacific Costa Rica
}

\author{
Patricio Hernáez ${ }^{1,2,3, *}$, Tayler McLellan Clarke ${ }^{1}$, Catalina Benavides-Varela ${ }^{1,4}$, \\ Fresia Villalobos-Rojas ${ }^{1}$, Jaime Nívia-Ruiz ${ }^{1}$, Ingo S. Wehrtmannn ${ }^{1,4}$ \\ ${ }^{1}$ Unit for Fishery Research and Aquaculture (UNIP) of the Research Center for Marine Science and Limnology (CIMAR), \\ University of Costa Rica, Costa Rica \\ ${ }^{2}$ Ocean Museum (Museo del Mar), University Arturo Prat, Casilla 121 Iquique, Chile \\ ${ }^{3}$ Laboratory of Bioecology and Crustacean Systematics, Department of Biology, FFCLRP, University of Sao Paulo, \\ Posgraduate Program Av. Bandeirantes 3900, 14040-901, Ribeirão Preto, São Paulo, Brazil \\ ${ }^{4}$ School of Biology, University of Costa Rica, 2060 San José, Costa Rica
}

\begin{abstract}
The mantis shrimp Squilla biformis is the most conspicuous and abundant stomatopod captured during benthic trawling operations off the Pacific coast of Costa Rica. Due to its abundance, this species is considered a potential fisheries resource for the region. Nevertheless, its life history is practically unknown. The present study describes the population demography, spatial distribution and behaviour of $S$. biformis from Pacific Costa Rica. The population was principally composed of individuals between 20 and $32 \mathrm{~mm}$ carapace length (CL), forming 2 age groups. Individuals of 35 to $45 \mathrm{~mm} \mathrm{CL}$ and $>45 \mathrm{~mm}$ CL were poorly represented. We assume that larger individuals are more frequent at greater depths (probably on the continental slope), thus out of the reach of the fishing vessels used in our study. Males outnumbered females, as observed in other stomatopods. Visual evidence of their behaviour demonstrates that the adults in this species possess a benthic and pelagic life style. Largest numbers of individuals (50\% of the total) were found between 240 to $260 \mathrm{~m}$, the same bathymetric range that was historically occupied by commercial shrimps. This shift may be related to intense fishing activities. We observed a synchronized moulting of females and males during less luminous (third and fourth) lunar phases. The evolutionary development of a group moulting system could confer advantages to $S$. biformis in comparison to other stomatopods whose moulting process is individual and asynchronous.
\end{abstract}

KEY WORDS: Population biology $\cdot$ Moulting cycle $\cdot$ Behaviour $\cdot$ Central America $\cdot$ Shrimp fishery

\section{INTRODUCTION}

The order Stomatopoda is comprised of the so-called mantis shrimps, which occupy many marine habitats in shallow and deep waters. They are divided into 2 groups based on the morphology and function of their raptorial appendage (Caldwell \& Dingle 1976, Ahyong 2001): 'smashers' live in pre-existing cavities within hard substrates that are limited in abundance. In contrast, 'spearers' live in self-excavated burrows made of sand or mud that are not limited in abundance. 'Spear- ers' kill and feed on soft-bodied prey and are considered to be less aggressive than 'smashers' (Caldwell \& Dingle 1975). They have been less studied because of their deeper, murkier habitats and their non-agonistic behaviour (see review in Wortham-Neal 2002).

'Spearers' are fished commercially in many parts of the world, principally in the Mediterranean (e.g. Squilla mantis Linnaeus, 1758: Abelló \& Martin 1993), Japan (Oratosquilla oratoria de Haan, 1844: Kubo et al. 1958), India (O. nepa Latreille, 1828: James \& Thirumilu 1993) and Australia (O. stephensoni Manning, 
1978: Dell \& Sumpton 1999). In contrast to the abovementioned countries, and despite their abundance on the continental shelf of many countries of the region (see Hendrickx \& Salgado-Barragán 1994, Hendrickx 1995, Wehrtmann \& Echeverría-Sáenz 2007), stomatopods from the Pacific coast of America are completely neglected as a local fishery resource (Hendrickx \& Salgado-Barragán 1989),

With 8 species, Squilla is one of the most specious stomatopod genera off the Pacific coast of America (Hendrickx 1995). During the last 3 decades, Squilla and other stomatopods have been studied intensively, especially off the west coast of Mexico (ecology and population demography: Hendrickx \& SalgadoBarragán 1989, Hendrickx 1995, Hendrickx \& Sánchez-Vargas 2005; spatial distribution: Hendrickx 1984, Hendrickx \& Salgado-Barragán 1994, Hendrickx 1995). In contrast, our knowledge regarding the ecology of Squilla off Central America is far from complete.

The available information on representatives of this group off Central America focuses on taxonomy (Manning 1972, Manning \& Reaka 1979), geographic distribution (Schmitt 1940, Reaka \& Manning 1980, Dittel 1991, Vargas \& Cortés 1997), ecology (Schmitt 1940, Reaka \& Manning 1980, 1981), and population biology (Dittel 1991). In addition, a recent study on the crustacean fauna associated with the deep-water shrimp fishery provides general annotations on the abundance of stomatopods off the Pacific coast of Costa Rica (Wehrtmann \& Echeverría-Sáenz 2007); these authors refer to the mantis shrimp Squilla biformis Bigelow, 1891 as the most common by-catch species. However, published data on population demography and spatial distribution of $S$. biformis or any other of the 8 species of Squilla reported for the American Central Pacific (Hendrickx 1995) are not available.

Squilla biformis occurs along the Pacific coast from the Gulf of California, Mexico to Huacho, Peru (Chirichigno et al. 1982, Hendrickx \& Salgado-Barragán 1989, Hendrickx \& Salgado-Barragán 1991). The species inhabits muddy and sandy bottoms in the mesolittoral zone at depths between 25 and $518 \mathrm{~m}$ (Hendrickx \& Sánchez-Vargas 2005); however, S. biformis in Central America can be found mainly from 200 to 300 m (Wehrtmann \& Echeverría-Sáenz 2007). In order to understand the prominent role of this stomatopod in deep-water systems and its importance as by-catch in the commercial shrimp fishery along the Pacific coast of Costa Rica (Wehrtmann \& Nielsen-Muñoz 2009), it is necessary to obtain adequate information about its population demography. Additionally, we present data on spatial distribution, the relationship between the moulting cycle of $S$. biformis and lunar phases, and video observations of the behaviour of this species.
Such information may provide valuable insights into the ecology of this mantis shrimp and its role in the multispecies deep-water fishery along the Pacific coast of Central America.

\section{MATERIALS AND METHODS}

Stomatopod sampling. Fieldwork was conducted along the Pacific coast of Costa Rica. Population demography was analyzed by collecting monthly samples (September 2007 to September 2008) of mantis shrimps, mainly from the central zone of the Pacific Costa Rican coast (Fig. 1A). Spatial distribution and abundance were analyzed by examining the material collected during 2 research cruises in August 2008 (rainy season) and May 2009 (dry season) along the entire Pacific coast (Fig. 1B; Table 1). All samples were collected from commercial shrimp trawlers $(22.5 \mathrm{~m}$ in length, $270 \mathrm{hp}$ ) equipped with 2 standard epibenthic nets (20.5 m long; mouth opening of $5.35 \times 0.85 \mathrm{~m}$; mesh size $4.5 \mathrm{~cm}_{\text {; }}$ cod-end mesh size $3.0 \mathrm{~cm}$ ); sampling duration was $20 \mathrm{~min}$ at a speed of 2.0 knots $\left(\sim 3.7 \mathrm{~km} \mathrm{~h}^{-1}\right)$. Initial and final positions were recorded with a GPS, and fishing depth by an echo-sounder. The ships 'Onuva' and 'Sultana', owned by The Rainbow Jewels, were equipped especially for scientific purposes as part of a joint project with this company undertaken by the University of Costa Rica since 2003. Sampling depth varied from 140 to $350 \mathrm{~m}$, covering the depth range of Squilla biformis previously reported by Wehrtmann \& Echeverría-Sáenz (2007). Bottom temperature and salinity were recorded with a CTDSBE25. Stomatopods were separated from the catch, and a sample was stored in ice water and subsequently frozen in the laboratory of the Unit for Fishery Research and Aquaculture (UNIP) of the Research Center for Marine Science and Limnology (CIMAR), University of Costa Rica, Costa Rica.

Population demography. Specimens were sexed according to the criteria described in the literature (e.g. Bigelow 1894, Griffiths \& Blaine 1988, Dittel 1991, Wortham-Neal 2002), and measured (CL, carapace length: from the anterior to the posterior margins of the carapace without rostrum $; \pm 0.1 \mathrm{~mm}$ ).

The CL was considered as an independent variable; adjustment of each regression was analyzed by least squares method (Sokal \& Rohlf 1995). This procedure was applied to males and females. Specimens of each category were grouped into $1 \mathrm{~mm}$ size classes; subsequently data were plotted as monthly lengthfrequency histograms to analyze the shrimp population structure. The normal component of each sample was separated using the Battacharya method included in FISAT software (Gayanilo et al. 1996). This analysis, 


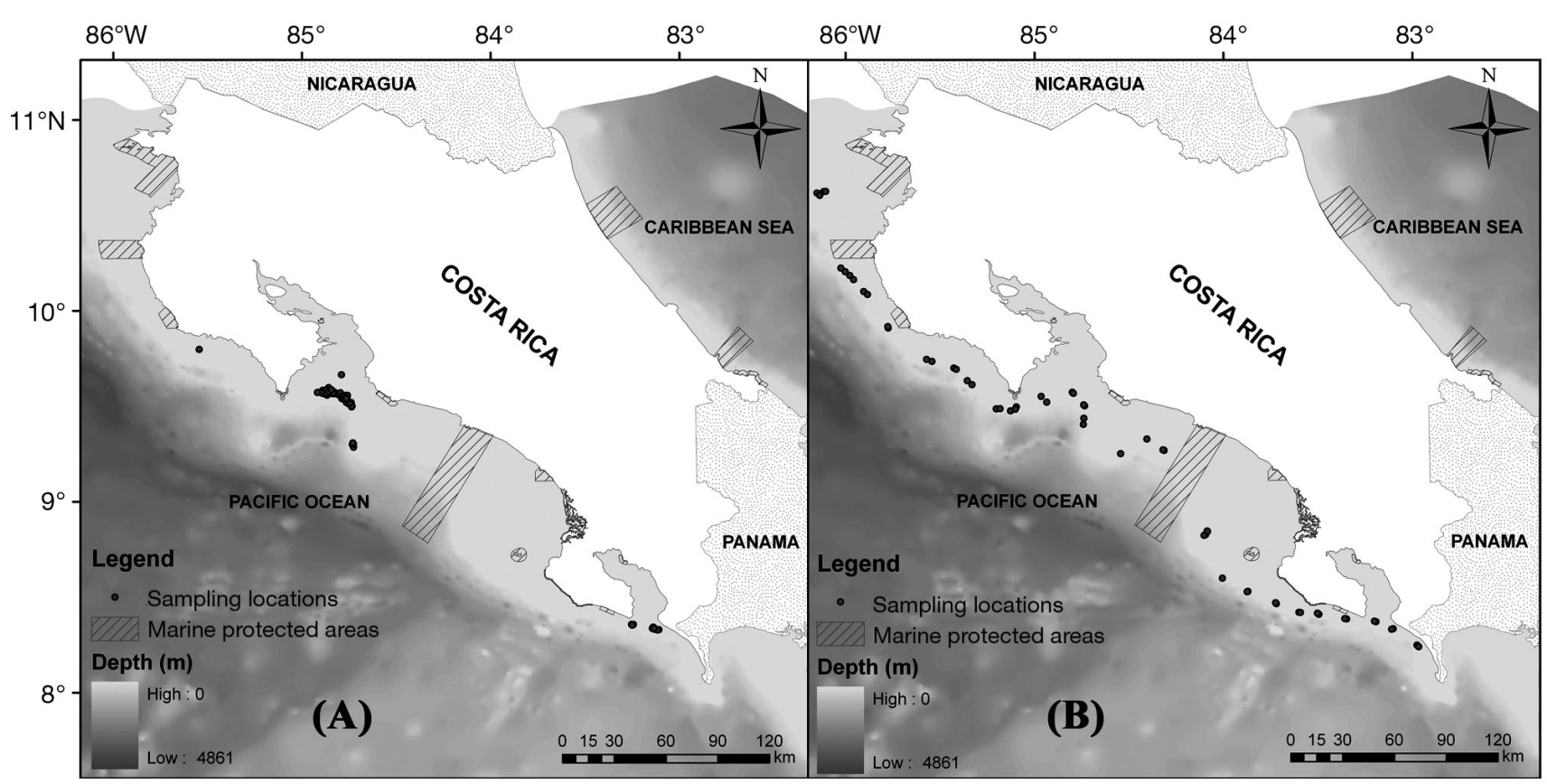

Fig. 1. Sampling sites along the Pacific coast of Costa Rica. Squilla biformis specimens were collected in the frame of (A) a monthly sampling programme (September 2007 to September 2008) and (B) 2 research cruises (August 2008, May 2009)

based on the identification of each cohort's mean, allowed separation of each modal component (see Gayanilo et al. 1996).

Knowledge of stomatopod larvae, both taxonomically and ecologically, is limited. Of the $\sim 350$ known stomatopod species, only $\sim 10 \%$ can be identified at their larval stages (Diaz \& Manning 1998). The information reported in some species of the Squilla genus indicates some kind of planktonic larval development (Morgan \& Provenzano 1979, Diaz 1998). Assuming that $S$. biformis has a larval planktonic development like other congeners (Morgan \& Provenzano 1979, Diaz 1998) and is benthic during juvenile and adult phases, we describe recruitment as the proportion of small individuals $(\leq 21 \mathrm{~mm} \mathrm{CL})$ using the 5th percentile method, a measure that is less prone to bias than that of the single smallest individual (Rivadeneira et al. 2010). This value was obtained from overall size frequency distributions. Monthly variations in sex ratios were analyzed applying $\chi^{2}$ tests $(1: 1 ; p<0.05$, Sokal \& Rohlf 1995).

The percentage of moulting males and females during each month was calculated as the ratio 'number of soft individuals:total number of individuals'. Moulting peaks of freshly moulted (soft) individuals were considered to be those months where $>40 \%$ of the population was undergoing ecdysis. A correlation test (Zar 1996) was applied to examine the possible synchronicity between male and female moulting patterns. The lunar phases (i.e. full moon, first quarter, new moon, and third quarter) were determined for each sample. The percentage of moulting individuals during each month was compared to the lunar phase in which they were collected, and also to temperature and depth.

Spatial distribution, abundance and behaviour. The spatial distribution of Squilla biformis was estimated through an explicit geographic correlation between the data obtained from the sampling sites. For each sampling location we estimated the mean, minimum and maximum body sizes (CL) according to sex, as well as the sex ratio. The minimum and maximum sizes were also estimated using the percentile method (5th and the 95th). The sex ratio (M:F) was determined and compared to a theoretical 1:1 ratio using the $\chi^{2}$ test (Sokal \& Rohlf 1995). A Spearman correlation test was used to analyze the relationship between mantis shrimp CL and sex, and the spatial distribution across the study area (Zar 1996).

In order to calculate the biomass, we used the swept area method (see Alverson \& Pereyra 1969). Using abundance (number of individuals) as a measure of biomass $(B)$, this is assumed to be a linear function of the population density $(D$, measured in weight or number of individuals per area unit, also known as 'catch per unit area' or CPUA) over the population's global distribution area $(A)$. It is assumed that the coefficient of proportionality is equal to the catchability coefficient ( $q$, Ricker 1975, see also Ralston \& Tagami 1992, Roa \& Bahamonde 1993 for specific applications). This relationship is represented as: 


$$
\begin{gathered}
B \cong A \times D \\
D \cong \frac{C}{\mathrm{AB}} \\
\mathrm{AB} \cong \mathrm{APA} \times \mathrm{DR}
\end{gathered}
$$

where $C$ represents the catch registered during each haul, the swept area (AB) is the product of the net's wing span (APA) and the covered distance (DR, in geographic coordinates). The covered distance (DR) of the area swept by the trawl on each haul was calculated using initial and final positions recorded by the GPS and Pythagoras' theorem corrected for latitudinal position (Sparre et al. 1989):

$\mathrm{DR}=60 \times \sqrt{\left\{\left(X_{i}-X_{j}\right)^{2}+\left(Y_{i}-Y_{j}\right)^{2} \times \cos \left[\frac{\left(\frac{X_{i}+X_{j}}{2}\right) \times \pi}{180}\right]\right\}^{2}}$

where $X_{i}$ and $X_{j}$ are the initial and final latitudes of the tow; $Y_{i}$ and $Y_{j}$ correspond to the tow's initial and final longitudes. In the absence of specific information, it was assumed that $q=1$. This value means that all individuals within the path swept by the trawl (and no others) were caught by the trawl. This assumption can be supported by the fact that no herding effect, which causes the capture of individuals from outside the swept area $(q>1)$, has been described for benthic crustaceans (Roa et al. 1995).

In order to document the behaviour of Squilla biformis in its habitat, we analyzed video tapes from 12 deployments off the central zone of the Pacific Costa Rican coast taken with a submarine belonging to DeepSee/Undersea Hunter Group (http://www. underseahunter. com/uh.htm). These videos were recorded off Herradura $\left(09^{\circ} 15^{\prime} 13^{\prime \prime} \mathrm{N}\right.$, $\left.84^{\circ} 26^{\prime} 57^{\prime \prime} \mathrm{W}\right)$ at between 300 and $320 \mathrm{~m}$ depth. All deployments were carried out between 08:00 and 12:00 $\mathrm{h}$, and each tape recorded observations lasting $\sim 10 \mathrm{~min}$. Each tape was viewed twice by one of us (P.H.) and 2 behaviour categories were used: (1) 'stationary' (shrimp standing relatively still) and (2) 'locomotory' (shrimp moving), each further broken into the following subcategories: (1a) resting on the sediment or (1b) inside the burrows; (2a) swimming, (2b) hunting, and (2c) walking.
Table 1. Squilla biformis. Latitudinal position of sampling sites, sampling depth

\begin{tabular}{|c|c|c|c|c|c|}
\hline \multicolumn{3}{|c|}{ — August 2008 (Rainy season) — } & \multicolumn{3}{|c|}{ — May 2009 (Dry season) } \\
\hline Latitude N & Depth (m) & CPUA & Latitude N & Depth (m) & CPUA \\
\hline $8^{\circ} 13^{\prime} 30^{\prime \prime}$ & 347 & 4.63 & $8^{\circ} 13^{\prime} 02^{\prime \prime}$ & 293 & 202.45 \\
\hline $8^{\circ} 18^{\prime} 46^{\prime \prime}$ & 256 & 11.68 & $8^{\circ} 18^{\prime} 34^{\prime \prime}$ & 247 & $6188.27^{*}$ \\
\hline $8^{\circ} 20^{\prime} 60^{\prime \prime}$ & 155 & 0 & $8^{\circ} 21^{\prime} 11^{\prime \prime}$ & 155 & 11.80 \\
\hline $8^{\circ} 21^{\prime} 58^{\prime \prime}$ & 256 & 820.79 & $8^{\circ} 22^{\prime} 04^{\prime \prime}$ & 238 & 701.50 \\
\hline $8^{\circ} 23^{\prime} 31^{\prime \prime}$ & 347 & 69.22 & $8^{\circ} 23^{\prime} 52^{\prime \prime}$ & 302 & 157.54 \\
\hline $8^{\circ} 24^{\prime} 11^{\prime \prime}$ & 256 & 36.24 & $8^{\circ} 24^{\prime} 08^{\prime \prime}$ & 238 & 494.93 \\
\hline $8^{\circ} 27^{\prime} 00^{\prime \prime}$ & 155 & 11.54 & $8^{\circ} 27^{\prime} 17^{\prime \prime}$ & 146 & 0.44 \\
\hline $8^{\circ} 30^{\prime} 54^{\prime \prime}$ & 256 & 6.83 & $8^{\circ} 30^{\prime} 49^{\prime \prime}$ & 247 & 0 \\
\hline $8^{\circ} 35^{\prime} 07^{\prime \prime}$ & 347 & 6.06 & $8^{\circ} 48^{\prime} 35^{\prime \prime}$ & 256 & 3690.60 \\
\hline $8^{\circ} 48^{\prime} 51^{\prime \prime}$ & 256 & 0.30 & $8^{\circ} 49^{\prime} 50^{\prime \prime}$ & 183 & 287.47 \\
\hline $8^{\circ} 49^{\prime} 58^{\prime \prime}$ & 183 & 104.04 & $9^{\circ} 15^{\prime} 38^{\prime \prime}$ & 260 & 18.69 \\
\hline $9^{\circ} 14^{\prime} 29^{\prime \prime}$ & 155 & 2.97 & $9^{\circ} 19^{\prime} 05^{\prime \prime}$ & 165 & 413.70 \\
\hline $9^{\circ} 15^{\prime} 26^{\prime \prime}$ & 274 & 83.52 & $9^{\circ} 25^{\prime} 43^{\prime \prime}$ & 329 & 0 \\
\hline $9^{\circ} 23^{\prime} 47^{\prime \prime}$ & 347 & 1200.35 & $9^{\circ} 28^{\prime} 39^{\prime \prime}$ & 219 & 31.78 \\
\hline $9^{\circ} 28^{\prime} 11^{\prime \prime}$ & 256 & 57.31 & $9^{\circ} 28^{\prime} 52^{\prime \prime}$ & 347 & 5785.89 \\
\hline $9^{\circ} 28^{\prime} 50^{\prime \prime}$ & 347 & $3235.99^{*}$ & $9^{\circ} 29^{\prime} 55^{\prime \prime}$ & 256 & 672.15 \\
\hline $9^{\circ} 29^{\prime} 39^{\prime \prime}$ & 256 & 15.89 & $9^{\circ} 30^{\prime} 50^{\prime \prime}$ & 347 & 80.34 \\
\hline $9^{\circ} 33^{\prime} 56^{\prime \prime}$ & 155 & 0 & $9^{\circ} 32^{\prime} 41^{\prime \prime}$ & 247 & 251.52 \\
\hline $9^{\circ} 37^{\prime} 45^{\prime \prime}$ & 165 & 0 & $9^{\circ} 33^{\prime} 35^{\prime \prime}$ & 161 & 205.31 \\
\hline $9^{\circ} 41^{\prime} 42^{\prime \prime}$ & 256 & 92.94 & $9^{\circ} 36^{\prime} 27^{\prime \prime}$ & 146 & 1.06 \\
\hline $9^{\circ} 44^{\prime} 30^{\prime \prime}$ & 247 & 43.19 & $9^{\circ} 41^{\prime} 20^{\prime \prime}$ & 247 & 12.59 \\
\hline $9^{\circ} 54^{\prime} 25^{\prime \prime}$ & 165 & 36.48 & $9^{\circ} 43^{\prime} 50^{\prime \prime}$ & 219 & 1.78 \\
\hline $10^{\circ} 05^{\prime} 56^{\prime \prime}$ & 256 & 2465.24 & $9^{\circ} 54^{\prime} 53^{\prime \prime}$ & 146 & 2.17 \\
\hline $10^{\circ} 10^{\prime} 60^{\prime \prime}$ & 183 & 221.14 & $10^{\circ} 04^{\prime} 60^{\prime \prime}$ & 247 & 90.05 \\
\hline $10^{\circ} 13^{\prime} 21^{\prime \prime}$ & 256 & 1761.98 & $10^{\circ} 09^{\prime} 40^{\prime \prime}$ & 192 & 11.04 \\
\hline $10^{\circ} 36^{\prime} 58^{\prime \prime}$ & 183 & 133.81 & $10^{\circ} 12^{\prime} 11^{\prime \prime}$ & 247 & 15.13 \\
\hline \multirow[t]{2}{*}{$10^{\circ} 37^{\prime} 25^{\prime \prime}$} & 155 & 5.81 & $10^{\circ} 36^{\prime} 14^{\prime \prime}$ & 146 & 283.57 \\
\hline & & & $10^{\circ} 37^{\prime} 29^{\prime \prime}$ & 146 & 1473.21 \\
\hline
\end{tabular}
and catch per unit area (CPUA, $\mathrm{kg} \mathrm{ha}^{-1}$ ) during 2 cruises along the Pacific coast of Costa Rica in August 2008 and May 2009. ${ }^{*}=$ biomass peak in each period

\section{RESULTS}

Population demography

A total of 1863 individuals were analyzed in monthly samples (September 2007 to September 2008) of which $56.8 \%$ were males and $43.2 \%$ females. Males were statistically ( $t$-test, $\mathrm{p}<0.01$ ) larger than females $(27.4 \pm 6.30 \mathrm{~mm} \mathrm{CL}$ and $25.0 \pm 5.51 \mathrm{~mm} \mathrm{CL}$, respectively). The majority of individuals ( $80 \%)$ were in the range of 22.0 to $29.0 \mathrm{~mm} \mathrm{CL}$. We detected large specimens (between 47 and $61 \mathrm{~mm} \mathrm{CL} ; 4 \%$ of the total) in a sample collected in November 2007 in the northern zone of the Pacific Costa Rican coast $\left(9^{\circ} 52^{\prime} \mathrm{N}, 85^{\circ} 38^{\prime} \mathrm{W}\right)$ at $292 \mathrm{~m}$ depth (Fig. 2). The cohort analysis confirmed the general presence of 2 cohorts throughout the year, with the exception of November and October 2007 where 5 and 3 cohorts were found, respectively, and February and March where only 1 cohort was found (Fig. 2).

The monthly mean body size fluctuated between $22.5 \mathrm{~mm}$ CL (September 2008) and $29.9 \mathrm{~mm}$ (March 2008). Monthly evolution of body sizes was significantly correlated to the percent- 
age of recruited individuals each month (Spearman, $\mathrm{R}=-0.62, \mathrm{p}<0.05$ ) (Fig. 3). The monthly entry of small individuals ( $\leq 21 \mathrm{~mm} \mathrm{CL}$ ) into the benthic population was generally below $6 \%$ throughout the year; the only exception was September 2008, when the percentage of recruits was $32 \%$ (26 recruits) (Fig. 3). During almost half of the study period, the sex ratio differed significantly from 1:1 (Fig. 2). With the exception of September 2007 and 2008, and February 2008, males were sig- nificantly more numerous than females (Fig. 2). The bottom temperature varied between $11.7^{\circ} \mathrm{C}$ (September 2007) and $13.9^{\circ} \mathrm{C}$ (July 2008) with no statistically significant differences among months (ANOVA, p < 0.05). The same pattern was observed for salinity, which was relatively stable during the study period. Temperature and salinity during the dry season were slightly lower $\left(12.81^{\circ} \mathrm{C}, 34.84 \mathrm{psu}\right)$ than during the wet season $\left(13.05^{\circ} \mathrm{C}, 34.85 \mathrm{psu}\right)$.
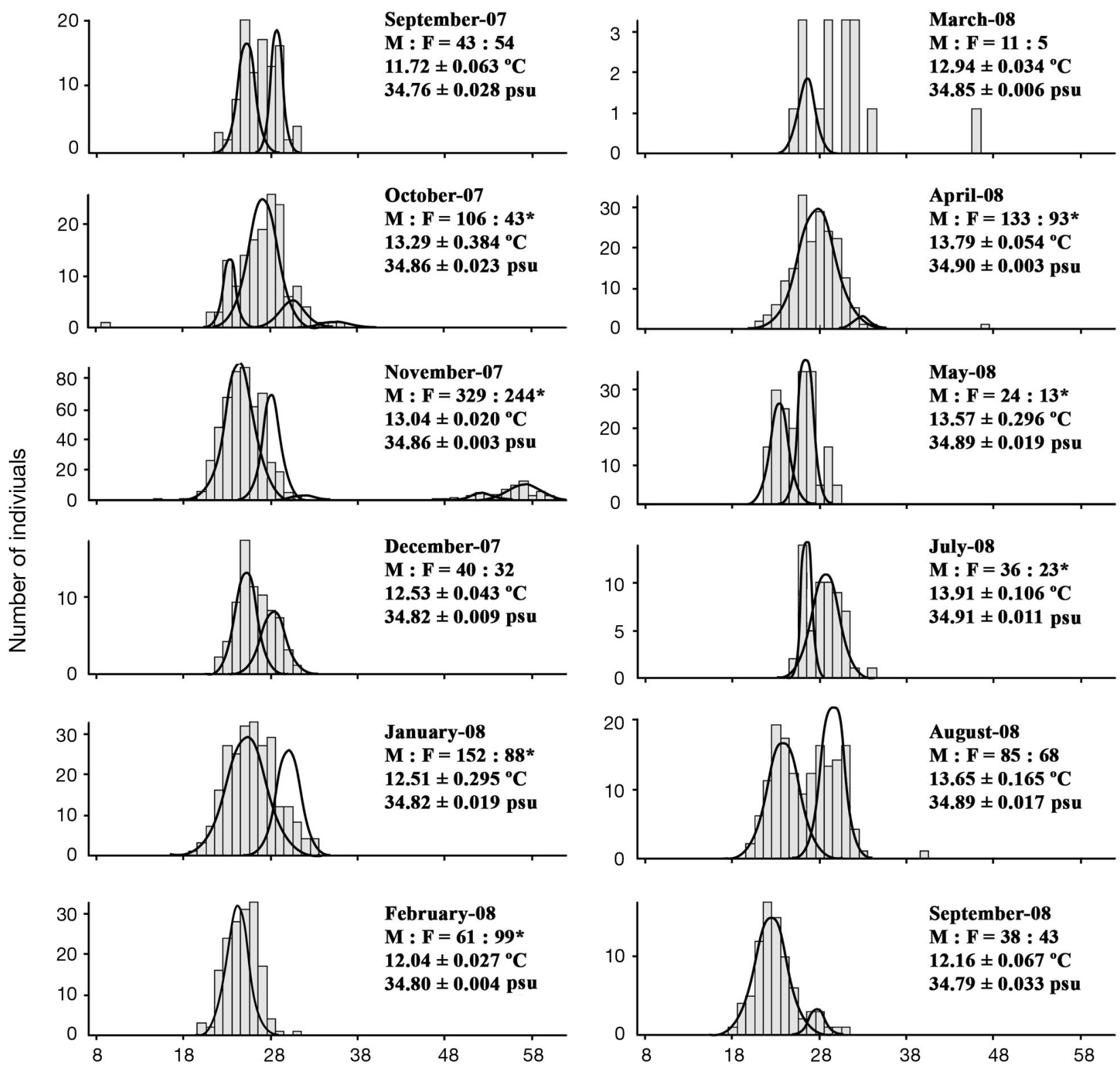

Carapace length (CL, $\mathrm{mm})$

Fig. 2. Squilla biformis. Monthly (September 2007 to September 2008) size frequency distribution from Pacific Costa Rica. Monthly cohorts are represented by normal distribution curves. The legend shows the sex ratio (M:F), mean bottom water temperature $\left({ }^{\circ} \mathrm{C}\right)$, and mean salinity (psu) for each month. ${ }^{*}=$ ratio significantly different $\left(\mathrm{p}<0.05 ; \chi^{2}\right.$ test) from $1: 1$. No sample was taken in June 2008 


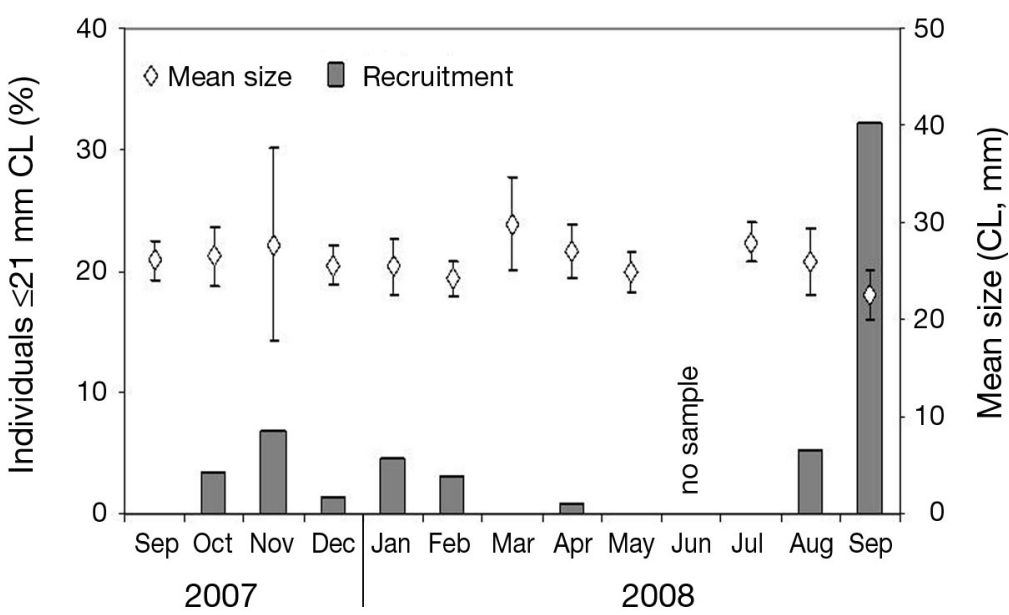

Fig. 3. Squilla biformis. Size distribution (mean \pm SD) and percentage of individuals $\leq 21 \mathrm{~mm} C L$ (recruiting individuals; $\mathrm{n}=97$ ) from the Pacific coast of Costa Rica during the study period (September 2007-September 2008)

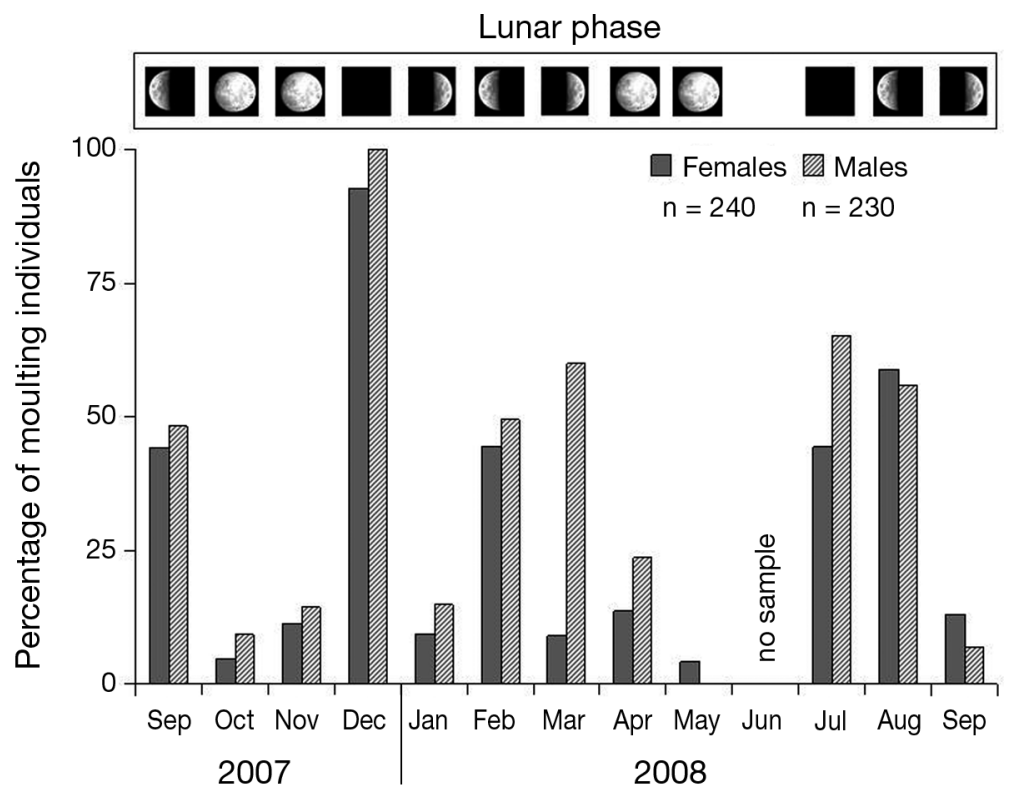

Fig. 4. Squilla biformis. Monthly (September 2007-September 2008) percentage of freshly moulted (soft) individuals found in samples collected along the Pacific coast of Costa Rica, with the corresponding lunar phases

moulted in December, September and August (ANOVA, p > 0.05). On the other hand, there was no statistically significant correlation (Pearson, $p>0.05$ ) between the percentage of recently-moulted individuals and temperature or salinity. However, except in March 2008, we observed a strong correlation between the moulting peaks of Squilla biformis and the third and fourth lunar phases (Fig. 4).

\section{Spatial distribution, abundance and behaviour}

A total of 1778 individuals (890 males, 888 females) was collected during 2 research cruises (August 2008: $\mathrm{n}=616$ ind., May 2009: $\mathrm{n}=1162$ ind.). Squilla biformis was present in $87 \%$ of all trawls ( $n=55$ ) and the spatial aggregation pattern revealed a continuous distribution (Fig. 5). Vertical distribution ranged from 146 to $347 \mathrm{~m}$ depth, and the largest numbers of individuals were found between 240 to $260 \mathrm{~m} \mathrm{(50 \% )}$ and from 340 to $360 \mathrm{~m}$ depth (14\%) (Fig. 6). The size of individuals collected in August (2008) and May (2009) varied between 16.4 and $43.3 \mathrm{~mm}$ CL. The mean body size (CL) tended to decrease significantly with depth (August 2008: $\mathrm{R}=$ -0.56, $\mathrm{p}<0.05, \mathrm{n}=11$; May 2009: $\mathrm{R}=$ -0.68, $\mathrm{p}<0.05, \mathrm{n}=11$ ) (Fig. 7).

The mean body size (CL) per sampling station was not correlated with latitude (Fig. 7). However, when using all individual measurements of all sampling locations, body size decreased significantly with increasing latitude (Spearman, females: $\mathrm{R}=-0.56, \mathrm{p}<0.05, \mathrm{n}=318$; males: $\mathrm{R}=$ $-0.26, \mathrm{p}<0.05, \mathrm{n}=298)$. The sex ratio remained balanced (1:1) in half of all sampled stations $\left(\chi^{2}\right.$ test, $\left.\mathrm{p}>0.05\right)$ and did not reveal a latitudinal trend. However, at some stations, males significantly outnum-

Moulting of females and males showed a synchronous pattern with 5 synchronized moulting peaks during the sampling period: in September and December the mean body sizes were $26.0 \pm 0.36$ and $25.6 \pm$ $0.29 \mathrm{~mm} \mathrm{CL}$, while in February this value was $24.4 \pm$ $0.28 \mathrm{~mm}$ CL and in July and August 2008 the mean body sizes were $27.8 \pm 0.43$ and $26.4 \pm 0.26 \mathrm{~mm} \mathrm{CL}$; a further peak in March 2008 (26.5 \pm 0.95) was constituted exclusively by males (Fig. 4). A statistical analysis showed similar mean sizes (CL) of individuals that bered females and vice versa. Although it was possible to find unbalanced sex ratios in all depths $\left(\chi^{2}\right.$ test, $\mathrm{p}<$ $0.05)$, the overall sex ratio was not related with depth.

In several sampling sites, CPUA reached $>1000 \mathrm{~kg}$ $\mathrm{ha}^{-1}$, with maximum values recorded in the central (August 2008) and southern regions (May 2009) of the study area (Table 1). Total biomass was higher in the dry season in May 2009 than in the rainy season in August 2008. During August 2008, a total of 10428 kg was obtained, while in May 2009 a total of $21054 \mathrm{~kg}$ was captured. 


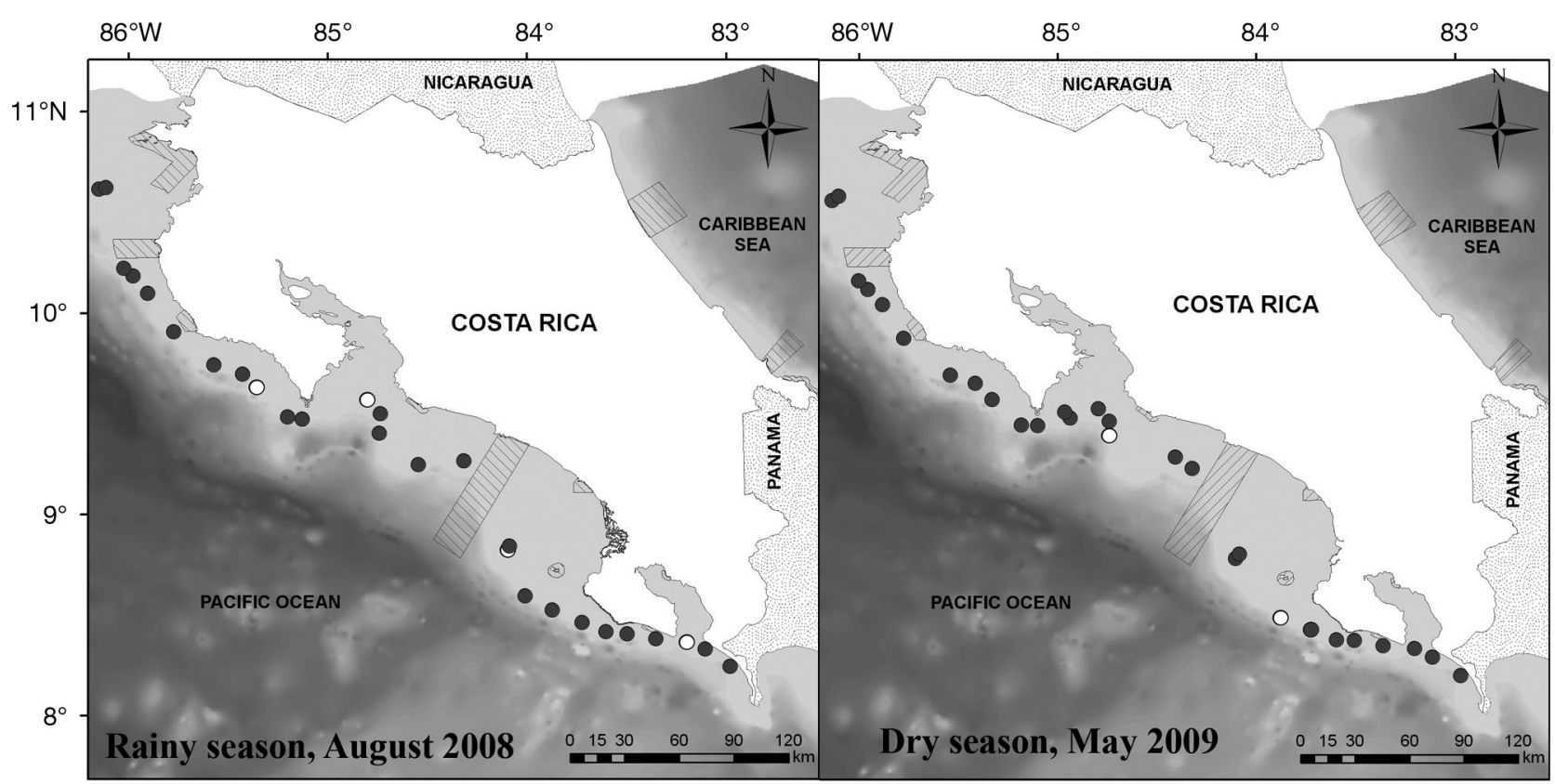

Fig. 5. Squilla biformis. Presence (๑) and absence (O) during cruises along the Pacific coast of Costa Rica in August 2008 and May 2009

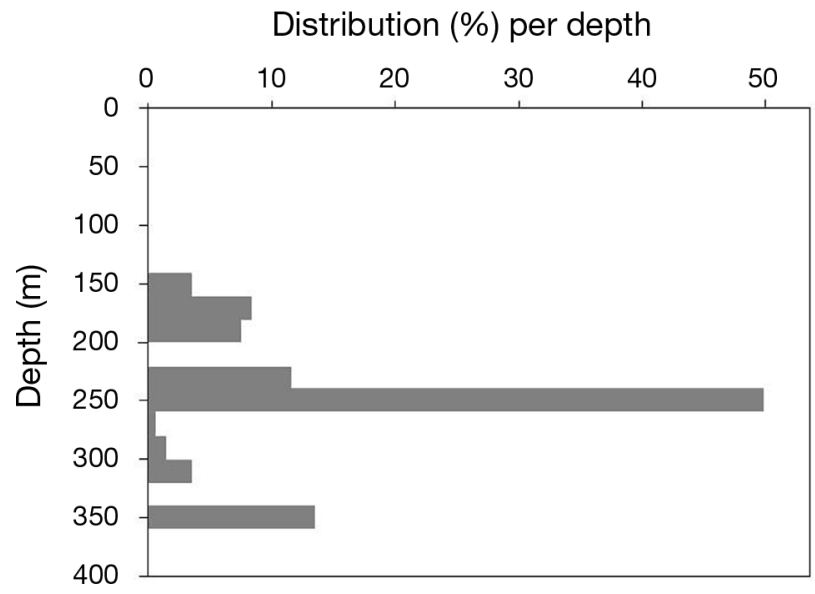

Fig. 6. Squilla biformis. Depth distribution of specimens collected during August 2008 and May 2009 along the Pacific coast of Costa Rica, showing presence (\%) of the individuals $(n=1778)$ per depth. Samples were obtained exclusively between 140 and $350 \mathrm{~m}$

Likewise, the maximum density value registered during the rainy season (3235 $\mathrm{kg} \mathrm{ha}^{-1}$ ) was considerably lower than the maximum density observed during the dry season (6188 kg ha-1). Generally the CPUA was higher in samples taken during the cruise in May 2009 (Table 1).

The video tapes revealed that Squilla biformis occurred on the bottom as well as between 10 and $15 \mathrm{~m}$ above the sea bed. The specimens displayed diverse behaviours (Fig. 8). Many individuals were observed resting or walking on the sediment (benthic lifestyle), but a similar proportion was observed swimming in the water column (pelagic lifestyle). The most commonly observed behaviour was resting on the sediment, followed by swimming (Fig. 9).

\section{DISCUSSION}

\section{Population demography, spatial distribution and behaviour of Squilla biformis}

Information on stomatopods from the Central American Pacific is scarce. Most of our knowledge refers to the results published by Dittel (1991), who partially analyzed the population demography of 4 species of shallow water stomatopods inhabiting the Gulf of Nicoya, Costa Rica.

In general, the Squilla biformis 35 to $45 \mathrm{~mm}$ CL size class was practically absent during our study period, corresponding to 0.1 and $0.6 \%$ of the individuals collected during the monthly sampling program and the 2 scientific cruises, respectively. A similar situation occurred with individuals $>45 \mathrm{~mm}$ CL $(3.5 \%)$, which were only found in the monthly catches. According to Hendrickx (1995), Squilla biformis is frequently found at the limit between the continental shelf and slope. Accordingly, we assume that larger individuals are more frequent at greater depths (probably on the continental slope), thus out of the reach of the fishing vessels used in our study. Another possible explanation for the scarcity of larger individuals in our bottom trawls is 

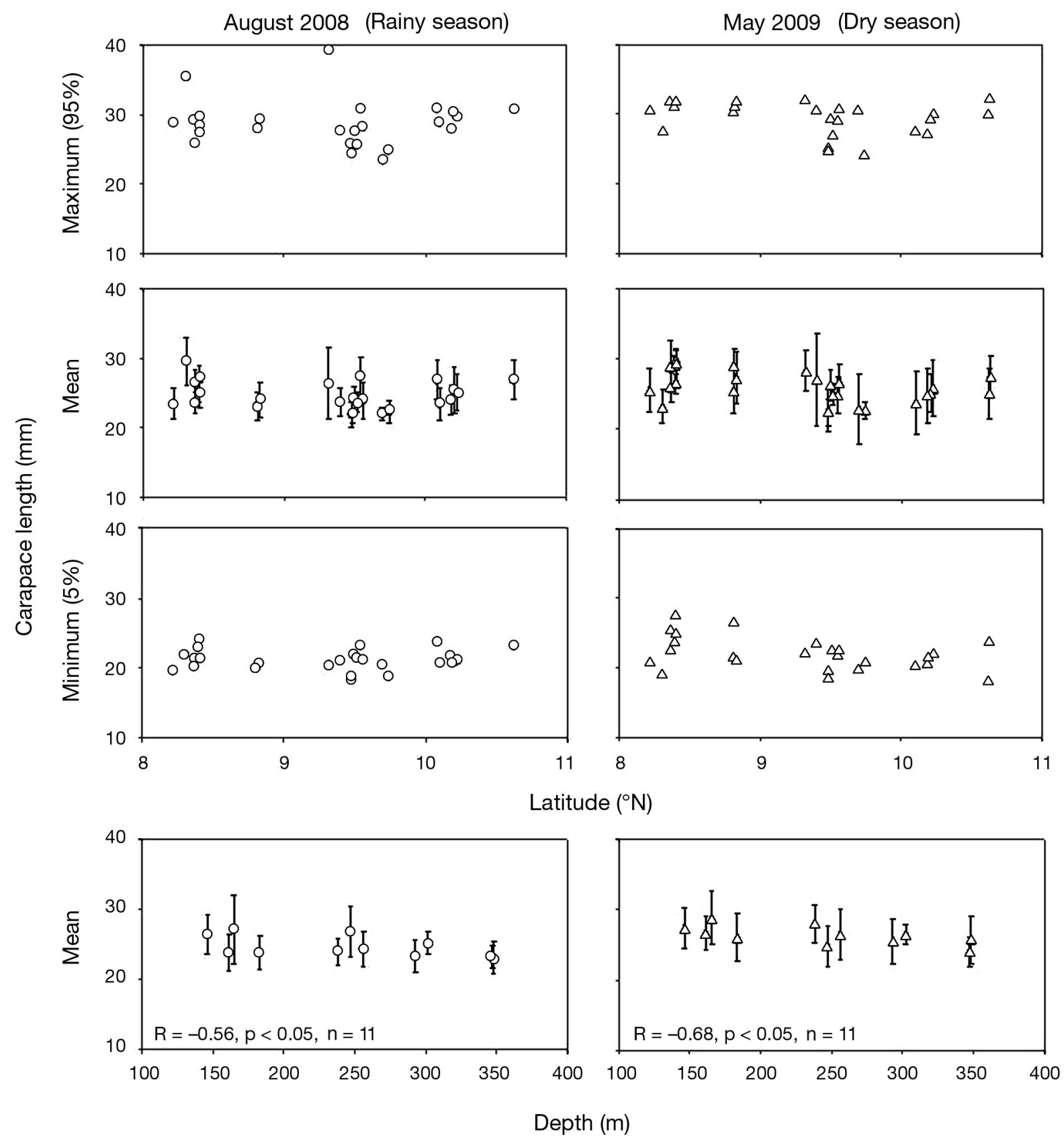

Fig. 7. Squilla biformis. Size (CL) of specimens in samples collected in August 2008 and May 2009 along the Pacific coast of Costa Rica, according to latitude and depth. Error bars: \pm SD

that these specimens may be common in the water column; however, we cannot substantiate this assumption, because the video images examined by us did not allow us to measure the size of observed individuals.

Some surveys conducted off the Mexican coast (Hendrickx 1984, Hendrickx \& Salgado-Barragán 1994, Hendrickx \& Sánchez-Vargas 2005), and along the Pacific coast of America (Hendrickx \& SalgadoBarragán 1991) showed that Squilla biformis is fre- quently found between 61 and $118 \mathrm{~m}$, and more frequently below 100 m (Hendrickx \& Sánchez-Vargas 2005). However the total range of vertical distribution in S. biformis is between 25 to $518 \mathrm{~m}$ (Schmitt 1940, Brusca 1980), and all the studies mentioned above sampled to a maximum depth of only $150 \mathrm{~m}$. Our sampling reached a greater depth and thus provides a broader picture of the vertical distribution of the entire population. The individuals between 20 and $35 \mathrm{~mm} \mathrm{CL}$ 

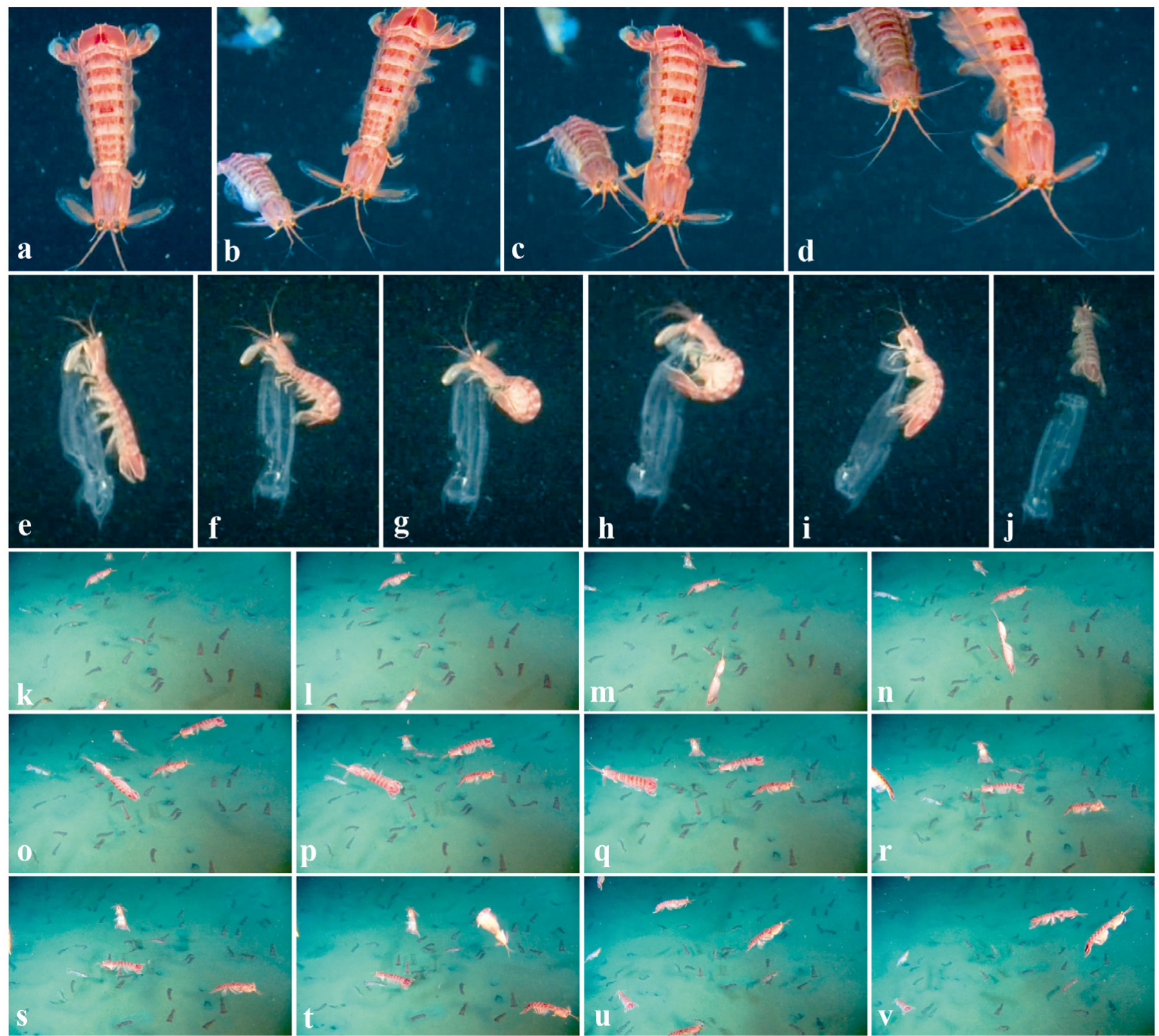

Fig. 8. Squilla biformis. Images obtained from a video taken by the Deep-See/Undersea Hunter Group (between 300 and $320 \mathrm{~m}$ depth) at the Pacific coast of Costa Rica (off Herradura: $09^{\circ} 25^{\prime} \mathrm{N}, 84^{\circ} 45^{\prime} \mathrm{W}$ ). The frames show close-ups of swimming specimens (a to d), a gelatinous structure being manipulated by one of mantis shrimp (e to j), and specimens on bottom displaying diverse behaviours ( $\mathrm{k}$ to $\mathrm{v})$

(95\% of the total caught) were represented at all depths from 140 to $350 \mathrm{~m}$; however, they were especially abundant (50\%) between 240 and $260 \mathrm{~m}$.

In Mexico, Squilla biformis occurs on muddy bottoms (silt and clay) between 61 to $117 \mathrm{~m}$, where dissolved oxygen levels are very low (0.37 to $0.55 \mathrm{ml} \mathrm{l}^{-1}$ ) (Hendrickx 1984). Vertical distribution and migration of marine invertebrates are often restricted by the oxygen minimum zone (OMZ), which extends vertically from about 50 to $1200 \mathrm{~m}$ in the eastern Pacific, with considerable variations depending on location, currents and other factors (Fernández-Álamo \& Färber-
Lorda 2006). The thickness of the OMZ varies from 600 to $200 \mathrm{~m}$ in the south Pacific and from 1100 to $400 \mathrm{~m}$ in the north Pacific. In Central America, specifically in Costa Rica, the upper boundary of the OMZ is located at 40 to $60 \mathrm{~m}$ (Fiedler \& Talley 2006), a depth below which $95 \%$ of $S$. biformis were found. Many organisms are adapted to these oxygen-deficient zones (Longhurst 1967, Mullins et al. 1985) and use it as a refuge or feeding zone (Wishner et al. 1995). It is speculated that $S$. biformis is adapted to these low oxygen conditions, and that observed swimming behaviour is a strategy that may be associated with the search for food or with 


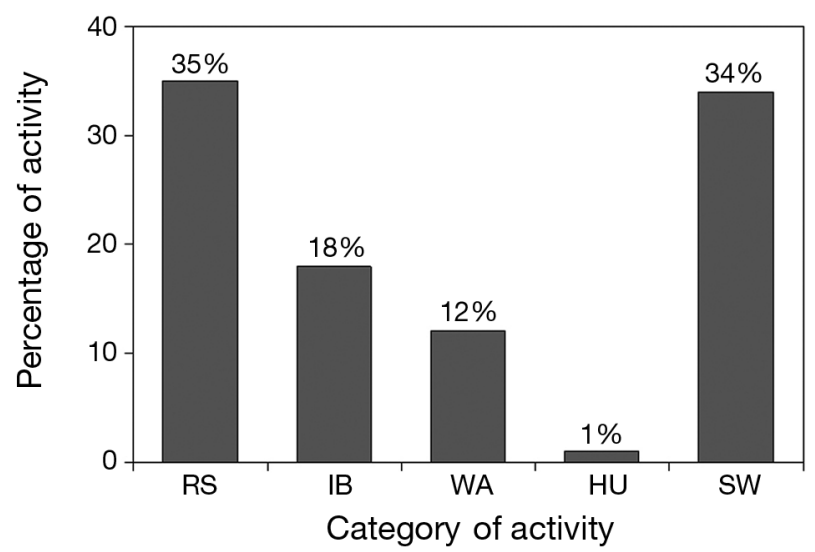

Fig. 9. Squilla biformis. Percentage of total activities spent on stationary (RS: resting on the sediment, IB: inside of the burrows) and locomotory behaviour (WA: walking, HU: hunting, SW: swimming) observed during 12 camera deployments conducted at various locations along the central Pacific coast of Costa Rica ( $\mathrm{n}=4032$ ind.)

gaining access to the layer above the oxygen minimum zone. Additional studies are required to corroborate this hypothesis.

Recruits ( $\leq 21 \mathrm{~mm} \mathrm{CL}$ ) were present from August 2007 to February 2008 and in April 2008. This recruitment pattern could reflect an extensive reproductive period, a common feature of organisms living in deepwater environments (see Sastry 1983). According to Orton (1920), such a pattern may be related to the relative temperature stability that allows continuous reproduction in many deep-water invertebrates. Since the bottom temperatures in our study area did not vary by more than $2.5^{\circ} \mathrm{C}$ and the salinity remained practically constant, we assume that Squilla biformis has an extensive reproductive period similar to those reported for other deep-water decapod species (see Omori 1974, Wenner 1978, Company \& Sardà 1997).

During this study, males outnumbered females, confirming previous observations for Squila biformis and other squillid mantis shrimps, including $S$. hancocki Schmitt, 1940, S. mantoidea Bigelow, 1893 and S. pamamensis Bigelow, 1891 off the Mexican coast (Hendrickx \& Sánchez-Vargas 2005). According to Griffiths \& Blaine (1988), females prefer the safety of their burrows, especially when carrying eggs. In contrast, males can be found more often outside the burrows, thus making them more vulnerable to bottom trawling. However, bias in the sex ratio is very common in decapods (Wenner 1972), and has also been attributed to latitudinal (Defeo \& Cardoso 2002, Rivadeneira et al. 2010) and temporal variations (Wenner 1972, Bas et al. 2005). Although our data does not allow any robust conclusion about the observed predominance of males, we cannot exclude the possibility that females migrate (temporarily) out of our study area or into the water column, causing the observed bias. This interpretation is supported by the study of Hamano et al. (1987), who described a similar migration pattern for Oratosquilla oratoria.

Squilla biformis is one of the most abundant species associated with deep-water shrimp fishery along the Pacific coast of Costa Rica where this species represents $25 \%$ of the catches carried out between 301 and $350 \mathrm{~m}$ depth (Wehrtmann \& Echeverría-Sáenz 2007). Its incidental capture has increased considerably in the past years, contrasting with the concomitant decrease in catches of the commercially exploited deep-water shrimp species Solenocera agassizii Faxon, 1893 and Heterocarpus vicarius Faxon, 1893 (Wehrtmann \& Nielsen-Muñoz 2009). Our results indicate that $S$. biformis is particularly abundant on bottoms deeper than $240 \mathrm{~m}$, a depth level traditionally occupied by $H$. vicarius (Wehrtmann \& Echeverría-Sáenz 2007). This apparent shift may be related to intense fishing activities and the reduction (or disappearance) of $H$. vicarius stocks, creating a vacancy, which is now increasingly occupied by $S$. biformis populations. This tendency has also been observed in El Salvador (A. Olivares, unpubl. data), thus indicating that a significant change might be occurring in the marine ecosystem structure off Central America.

\section{Ecdysis process in Squilla biformis and its relationship to the lunar cycle}

Our results indicate a possible association between the moulting process in Squilla biformis and the lunar cycle (Fig. 4), as has been reported by other authors in different stomatopod species (Reaka 1976, Christy \& Salmon 1991). The presence of a high percentage of moulting individuals of both sexes during the third and fourth lunar phases is clear evidence of well-defined circalunar and synchronic rhythm in $S$. biformis.

The moult in both sexes of Squilla biformis occurred principally during the less luminous lunar phases (3rd and 4th phases) and apparently on the bottom. Moonlight plays a significant role in the vision of deep-water organisms, because it may penetrate much deeper than daylight (Denton 1990). The level of bright moonlight is about $3 \times 10^{-6}$ of that of sunlight, which means that on bright moonlit nights its contribution to submarine light at about $400 \mathrm{~m}$ is close to that found in full sunlight at about 800 m (Sathyendranath \& Platt 1990). The highly specialized visual system of stomatopods (see Marshall et al. 1999, Cronin et al. 2006) may allow them to detect small changes in the moonlight intensity, which in turn may trigger the moulting cycle. In our study, a close correlation between moult frequency in $S$. biformis and lu- 
nar phases is apparent, as was demonstrated by Reaka (1976) in stomatopods from shallow waters.

Moult synchrony is a common trait in crustaceans (e.g. euphausid shrimps) that form large aggregations of individuals (Buchholz 1985, Morris 1985). One hypothesis explains this synchronous behaviour as being related to fluctuations in food availability, which control the moulting cycle of the population (Buchholz 1991). Our data do not allow any conclusion about the possible relation between food fluctuations and the moulting cycle; however, the presence of simultaneously moulting individuals of $S$. biformis needs further attention.

In contrast to solitary mantis shrimps ('smashers'), 'spearers' like Squilla biformis form large aggregations of individuals and are less aggressive than 'smashers' (Caldwell \& Dingle 1975). This proposition is confirmed by our visual evidence of the main activities performed by $S$. biformis (see Fig. 8), which did not provide evidence of agonistic interactions. We assume that, like their other activities, the moulting cycle of $S$. biformis has developed in a way that avoids agonistic interactions. The sociable behaviour of $S$. biformis might reflect the evolution of a social moulting system that is advantageous in comparison with the individual and asynchronous moulting processes found in other stomatopods (see Reaka 1976).

Acknowledgements. The present study was partially financed by Ristic AG (Oberferrieden, Germany), and the Universidad de Costa Rica (projects V.I. 111-A4-508; V.I. 808-A9-536, and V.I. 808-A9-537). Additional funds came from the Consejo Superior Universitario Centroamericano (CSUCA), University of Kassel, and the Deutsche Gesellschaft für Technische Zusammenarbeit (GTZ) in the frame of the project Programa Universidad-Empresa para un Desarrollo Sostenible (PUEDES). Special thanks to Deep-See/Undersea Hunter Group (in the person of Shmulik Blum) for providing the images analyzed in this study; we appreciate that Jorge Cortés (Universidad de Costa Rica) informed us about the existence of these video tapes. We are thankful to the captains and crews of the shrimp trawlers 'Onuva' and 'Sultana' as well as to René Diers, The Rainbow Jewels. Last not least, we are more than grateful to all the students and assistants (especially Edgar Villegas and Juliana Herrera) who collaborated enthusiastically during the fieldwork. The Centro de Investigación en Ciencias del Mar y Limnología (CIMAR) and Escuela de Biología, Universidad de Costa Rica, provided working facilities to carry out this study, which is greatly appreciated. Finally, the constructive comments of 4 anonymous referees were greatly appreciated and helped to improve the quality of the manuscript.

\section{LITERATURE}

Abelló P, Martin P (1993) Fishery dynamics of the mantis shrimp Squilla mantis (Crustacea: Stomatopoda) population off the Ebro delta (north western Mediterranean). Fish Res 16:131-145

Alverson DL, Pereyra WT (1969) Demersal fish in the northeastern Pacific Ocean: an evaluation of exploratory fishing methods and analytical approaches to stock size and yield forecasts. J Fish Res Board Can 26:1985-2001

Ahyong ST (2001) Revision of the Australian stomatopod Crustacea. Rec Aust Mus 26:1-326

Bas C, Luppi T, Spivak E (2005) Population structure of the South American estuarine crab, Chasmagnathus granulatus (Brachyura: Varunidae) near the southern limit of its geographical distribution: comparison with northern populations. Hydrobiologia 537:217-228

Bigelow RP (1894) Report upon the Crustacea of the order Stomatopoda collected by the Steamer Albatross between 1885 and 1891, and on other specimens in the US National Museum. Proc US Nat Museum 17:489-550

Brusca RC (1980) Common intertidal invertebrates of the Gulf of California, 2nd edn. University of Arizona Press, Tucson, AZ

Buchholz F (1985) Moult and growth in euphausiids. In: Siegfried WR, Condy P, Laws RM (eds) Antarctic nutrient cycles and food webs. Proc 4th Symp Antarct Biol, Springer, Berlin, p 339-345

Buchholz F (1991) Moult cycle and growth of Antarctic krill Euphausia superba in the laboratory. Mar Ecol Prog Ser 69:217-229

Caldwell RL, Dingle H (1975) Ecology and evolution of agonistic behavior in stomatopods. Naturwissenschaften 62: 214-222

Caldwell RL, Dingle H (1976) Stomatopods. Sci Am 19: 126-133

Chirichigno N, Fischer W, Nauen CE (1982) INFOPESCA. Catálogo de especies marinas de interés económico actual o potencial para América Latina. Parte 2: Pacífico central y suroriental. SIC/82/2, FAO/PNUD, Roma

Christy JH, Salmon M (1991) Comparative studies of reproductive behavior in mantis shrimps and fiddler crabs. Am Zool 31:329-337

Company JB, Sardà F (1997) Reproductive patterns and population characteristics in five deep-water pandalid shrimps in the western Mediterranean along a depth gradient (150-1100 m). Mar Ecol Prog Ser 148:49-58

Cronin TW, Caldwell RL, Marshall J (2006) Learning in Stomatopod Crustaceans. Int J Comp Psychol 19:297-317

> Defeo O, Cardoso RS (2002) Macroecology of population dynamics and life history traits of the mole crab Emerita brasiliensis in Atlantic sandy beaches of South America. Mar Ecol Prog Ser 239:169-179

Dell Q, Sumpton W (1999) Stomatopod by-catch from prawn trawling in Moreton Bay, Australia. Asian Fish Sci 12: 133-144

Denton J (1990) Light and vision at depths greater than 200 metres. In: Herring PT, Campbell AK, Whitfield M, Maddock L (eds) Light and life in the sea. Cambridge University Press, Cambridge

Diaz GA (1998) Description of the last seven pelagic larval stages of Squilla sp. (Crustacea, Stomatopoda). Bull Mar Sci 62:753-762

Diaz GA, Manning RB (1998) The last pelagic stage and juvenile of Lysiosquilla scabricauda (Lamarck, 1818) (Crustacea, Stomatopoda). Bull Mar Sci 63:453-457

> Dittel A (1991) Distribution, abundance and sexual composition of stomatopods in the Gulf of Nicoya. J Crustac Biol 11:269-276

> Fernández-Álamo MA, Färber-Lorda J (2006) Zooplankton and the oceanography of the eastern tropical Pacific: a review. Prog Oceanogr 69:318-359

Fiedler PC, Talley LD (2006) Hydrography of the eastern tropical Pacific: a review. Prog Oceanogr 69:143-180

Gayanilo F, Sparre P, Pauly D (1996) FAO-ICLARM stock assessment tools: user's guide. FAO-ICLARM, Rome

Griffiths CL, Blaine MJ (1988) Distribution, population struc- 
ture and biology of stomatopod Crustacea of the west coast of South Africa. S Afr. J Mar Sci 7:45-50

Hamano T, Morrissy NM, Matsuura S (1987) Ecological information on Oratosquilla oratoria (Stomatopoda, Crustacea) with an attempt to estimate the annual settlement date from growth parameters. J Shimoneseki Univ Fish 36:9-27

Hendrickx ME (1984) Distribution and abundance of stomatopods (Cmstacea: Haplocarida) in Southern Sinaloa, Mexico. Rev Biol Trop 32:269-277

Hendrickx ME (1995) Estomatópodos. In: Fischer W, Krupp F, Schneider W, Sommer C, Carpenter KE, Niem VH (eds) Guía FAO para la identificación de especies para los fines de la pesca. Pacífico centro-oriental, Vol I: plantas e invertebrados. FAO, Rome, p 355-382

Hendrickx ME, Salgado-Barragán J (1989) Ecology and fishery of stomatopods in the Gulf of California. In: Ferrero EA (ed) Biology of stomatopods. Collana UZI: Selected Symposia and Monographs, Mucchi Editore, Modena, p 241-249

Hendrickx ME, Salgado-Barragán J (1991) Los estomatópodos (Crustacea: Hoplocarida) del Pacífico mexicano. Publ Esp Inst Cienc Mar Limnol UNAM 10:1-200

Hendrickx ME, Salgado-Barragán J (1994) Stomatopods (Crustacea: Hoplocarida) collected off the coasts of Sinaloa, Mexico, during the BIOCAPESS cruises IV, V and VI (August 1991, March and June 1992). An Inst Biol UNAM 65:217-231

Hendrickx ME, Sánchez-Vargas P (2005) Estomatópodos del género Squilla (Hoplocarida: Stomatopoda: Squillidae) recolectados frente a la costa de Sinaloa, en el SE del golfo de California, México, en los cruceros CEEMEX C1-C2C3. Cienc Mar 31(1A):31-41

James DB, Thirumilu P (1993) Population dynamics of Oratosquilla nepa in the trawling grounds off Madras. J Biol Asses India 35:135-140

Kubo I, Hori S, Kumemura M, Naganawa N, Soedjono J (1958) A biological study on a Japanese edible mantis shrimp, Squilla oratoria de Haan. J Tokyo Univ Fish 45: 1-26

Longhurst AR (1967) Vertical distribution of zooplankton in relation to the eastern Pacific oxygen minimum. Deep-Sea Res 14:51-63

Manning RB (1972) Eastern Pacific expeditions of the New York Zoological Society. Stomatopod Crustacea. Zoologica 56:95-113

Manning RB, Reaka ML (1979) Three new stomatopod crustaceans from the Pacific coast of Costa Rica. Proc Biol Soc Wash 92:634-639

Marshall NJ, Kent J, Cronin TW (1999) Visual adaptations in crustaceans. In: Archer S, Djamgoz M, Lowe E, Partridge JC, Vallerga S (eds) Adaptive mechanisms in the ecology of vision. Kluwer, London, p 285-328

Morgan SG, Provenzano AJ Jr (1979) Development of pelagic larvae and post-larva of Squilla empusa (Crustacea, Stomatopoda), with an assessment of larval characters within the Squillidae. Fish Bull US 77:61-90

Morris DJ (1985) Integrated model of moulting and feeding of Antarctic krill Euphausia superba off South Georgia. Mar Ecol Prog Ser 22:207-217

Mullins HT, Thompson JB, McDougall K, Vercoutere TL (1985) Oxygen minimum zone edge effects: evidence from central California coastal upwelling system. Geology 13: 491-494

Omori M (1974) The biology of pelagic shrimps in the ocean. Adv Mar Biol 12:233-324

Orton JH (1920) Sea temperature, breeding and distribution in marine animals. J Mar Biol Assoc UK 12:339-366

Ralston S, Tagami DT (1992) An assessment of the exploitable biomass of Heterocarpus laevigatus in the main Hawaiian islands. 1. Trapping surveys, depletion experiment, and length structure. Fish Bull US 90:494-504

Reaka ML (1976) Lunar and tidal periodicity of molting and reproduction in stomatopod Crustacea: a selfish herd hypothesis. Biol Bull 150:468-490

Reaka ML, Manning RB (1980) The distributional ecology and zoogeographical relationship of stomatopod Crustacea from Pacific Costa Rica. Smithson Contrib Mar Sci 7:1-29

> Reaka ML, Manning RB (1981) The behavior of stomatopod Crustacea, and its relationship to rates of evolution. J Crustac Biol 1:309-327

Ricker WE (1975) Computation and interpretation of biological statistics of fish populations. B Fish Res Board Can 191: $1-382$

Rivadeneira MM, Hernáez P, Baeza JA, Boltaña S and others (2010) Testing the abundant-centre hypothesis using intertidal porcelain crabs along the Chilean coast: linking abundance and life-history variation. J Biogeogr 37: 486-498

$>$ Roa R, Bahamonde R (1993) Growth and expansion of an exploited population of the squat lobster (Pleuroncodes monodon) after 3 years without harvesting. Fish Res 18:305-319

- Roa R, Gallardo VA, Ernst B, Baltazar M, Cañete JI, EnríquezBrionnes S (1995) Nursery ground, age structure and abundance of juvenile squat lobster Pleuroncodes monodon on the continental shelf off central Chile. Mar Ecol Prog Ser 116:47-54

Sastry A (1983) Ecological aspects of reproduction. In: Vernberg FJ, Vernberg WB (eds) The biology of Crustacea: environmental adaptations. Academic Press, New York, p 179-270

Sathyendranath S, Platt T (1990) The light field in the oceans: its modification and exploitation by the pelagic biota. In: Herring PT, Campbell AK, Whitfield M, Maddock L (eds) Light and life in the sea. Cambridge University Press, Cambridge

Schmitt WL (1940) The stomatopods of the west coast of America based on collection made by the Allan Hancock Expeditions, 1933-38. Allan Hancock Pac Exped 5:129-225

Sokal R, Rohlf F (1995) Biometry. The principles and practices of statistics in biological research. Freeman, New York

Sparre P, Ursin E, Venema SC (1989) Introduction to tropical fish stock assessment. FAO Fish Tech Pap 306/1, FAO, Rome

Vargas R, Cortés J (1997) Biodiversidad marina de Costa Rica: Orden Stomatopoda (Crustacea: Hoplocarida). Rev Biol Trop 45:1531-1539

> Wehrtmann IS, Echeverría-Sáenz S (2007) Crustacean fauna (Stomatopoda: Decapoda) associated with the deepwater fishery of Heterocarpus vicarius (Decapoda: Pandalidae) along the Pacific coast of Costa Rica. Rev Biol Trop 55: 121-126

Wehrtmann IS, Nielsen-Muñoz V (2009) The deepwater fishery along the Pacific coast of Costa Rica, Central America. Lat Amer J Aquat Res 37:543-554

Wenner AM (1972) Sex ratio as a function of size in marine Crustacea. Am Nat 106:321-350

Wenner EL (1978) Some aspects of the biology of deep-sea lobsters of the family Polychelidae (Crustacea. Decapoda) from the western North Atlantic. Fish Bull US 77:435-444

> Wishner KF, Ashjian CJ, Gelfman C, Gowing MM and others (1995) Pelagic and benthic ecology of the lower interface of the eastern tropical Pacific oxygen minimum zone. Deep Sea Res I 42:93-115

> Wortham-Neal JL (2002) Reproductive morphology and biology of male and female mantis shrimp (Stomatopoda: Squillidae). J Crustac Biol 22:728-741

Zar JH (1996) Biostatistical analysis. Prentice Hall, Englewood Cliffs, NJ 